\title{
Control of Motility in the Internal Anal Sphincter
}

\author{
Kathleen D Keef* and Caroline A Cobine \\ Department of Physiology and Cell Biology, University of Nevada, Reno School of Medicine, Reno, NV, USA
}

The internal anal sphincter (IAS) plays an important role in the maintenance of fecal continence since it generates tone and is responsible for $>70 \%$ of resting anal pressure. During normal defecation the IAS relaxes. Historically, tone generation in gastrointestinal muscles was attributed to mechanisms arising directly from smooth muscle cells, ie, myogenic activity. However, slow waves are now known to play a fundamental role in regulating gastrointestinal motility and these electrical events are generated by the interstitial cells of Cajal. Recently, interstitial cells of Cajal, as well as slow waves, have also been identified in the IAS making them viable candidates for tone generation. In this review we discuss four different mechanisms that likely contribute to tone generation in the IAS. Three of these involve membrane potential, L-type $\mathrm{Ca}^{2+}$ channels and electromechanical coupling (ie, summation of asynchronous phasic activity, partial tetanus, and window current), whereas the fourth involves the regulation of myofilament $\mathrm{Ca}^{2+}$ sensitivity. Contractile activity in the IAS is also modulated by sympathetic motor neurons that significantly increase tone and anal pressure, as well as inhibitory motor neurons (particularly nitrergic and vasoactive intestinal peptidergic) that abolish contraction and assist with normal defecation. Alterations in IAS motility are associated with disorders such as fecal incontinence and anal fissures that significantly decrease the quality of life. Understanding in greater detail how tone is regulated in the IAS is important for developing more effective treatment strategies for these debilitating defecation disorders.

(J Neurogastroenterol Motil 2019;25:189-204)

\section{Key Words}

Interstitial cells of Cajal; Receptor, platelet-derived growth factor alpha; Slow waves; Smooth muscle; Tone

\section{Introduction}

The internal anal sphincter (IAS) is an involuntary smooth muscle sphincter located at the distal extremity of the gastrointestinal (GI) tract. It is formed by a thickening of the circular muscle layer and is surrounded by skeletal muscle of the external anal sphincter (EAS). Defecation is regulated by the functions of both of these sphincters and associated pelvic floor muscles. The IAS plays a significant role in the maintenance of fecal continence since it is responsible for $>70 \%$ of resting anal pressure due to its ability to generate tone. ${ }^{1-4}$ Because of this barrier function, the IAS differs significantly from other GI muscles that are involved in the mixing, storage, and propulsion of luminal contents.

Alterations in IAS motility are associated with disorders such as fecal incontinence and anal fissures. These disorders are not life threatening but can result in a significant decrease in the quality of life. ${ }^{5,6}$ Decreased anal pressure can lead to fecal incontinence, while elevated anal pressure is observed in patients with an anal fissure due to hypercontractility of the IAS. ${ }^{7}$ Treatments for anal fissures include sphincterectomy, botulinum toxin injection, and topical application of glyceryl trinitrate, $\mathrm{L}$-type $\mathrm{Ca}^{2+}$ channel or $\alpha$-adrenoceptor blockers. ${ }^{8-10}$ Although relatively effective in treating this painful condition, in many instances, the treatment itself can

Received: October 25, 2018 Revised: November 28, 2018 Accepted: December 9, 2018

() This is an Open Access article distributed under the terms of the Creative Commons Attribution Non-Commercial License (http://creativecommons. org/licenses/by-nc/4.0) which permits unrestricted non-commercial use, distribution, and reproduction in any medium, provided the original work is properly cited.

${ }^{*}$ Correspondence: Kathleen D Keef, PhD Department of Physiology and Cell Biology, University of Nevada, Reno School of Medicine, Reno, NV 89557, USA Tel: +1-775-784-4302, Fax: +1-775-784-6903, E-mail: kkeef@med.unr.edu 
lead to fecal incontinence. Conversely, treatment of fecal incontinence has not been entirely successful to date. Current strategies include the use of bulking agents, biofeedback therapy, magnetic beads, sacral nerve stimulation, nerve grafts, topical application of $\alpha$-adrenoceptor agonists and most recently artificial sphincters and stem cell therapy. ${ }^{11-13}$ Many of these treatments are invasive, eg, surgical placement of a sacral nerve stimulator or magnetic beads, or have short-lived effects, eg, topical application of pharmacological agents. Bioengineered sphincters and stem cell therapy, while also invasive, are promising avenues but still early in the development phase. $^{13}$

Achieving a better understanding of the fundamental properties that underlie tone development in the IAS and the manner in which nerves modulate this activity are important goals for informing the development of more effective treatment strategies for the aforementioned debilitating defecation disorders. To follow is a review of our current understanding of the mechanisms underlying the control of IAS motility.

\section{Morphology of the Internal Anal Sphincter}

\section{Organization of Internal Anal Sphincter Smooth Muscle}

The IAS occupies the distal most section of the GI tract. Both circular and longitudinal muscle layers are present but these layers are separated by a sparsely occupied connective tissue space suggesting minimal electrical communication. ${ }^{14,15}$ The sphincter function of the IAS is mediated by the circular muscle layer. An important morphological feature of the circular muscle layer of the IAS is that it is divided into discrete bundles separated by connective tissue septa which we have referred to as "minibundles." In mouse, minibundles extend from the myenteric to the submucosal surface of the circular muscle layer with the entire width of the IAS consisting of only 5-8 minibundles. ${ }^{16}$ In contrast, the circular muscle layer of larger animals such as dog, sheep, monkey and human consists of numerous minibundles stacked next to one another in the transverse and longitudinal directions (Fig. 1). ${ }^{14,15,17,18}$ One consequence of this bundle arrangement is that there is significantly more connective tissue in the IAS than in muscles of the large intestine; a feature that likely contributes to the tensile strength of the IAS. The separation of minibundles by connective tissue septa is also likely to limit the degree to which adjacent bundles are electrically coupled to one another. This impacts how the contractions of individual minibundles summate; a concept that is discussed in subsequent sections.

\section{General Features of Interstitial Cells of Cajal}

In addition to smooth muscle, the "muscularis externa" of the GI tract contains a second cellular component with high expression levels of the receptor tyrosine kinase Kit. These $\mathrm{Kit}^{+}$cells are called interstitial cells of Cajal (ICC). ICC are widely recognized as the pacemaker cells of the GI tract, giving rise to slow waves (SWs). The conduction of SWs from ICC to adjacent smooth muscle cells (SMCs) via gap junctions gives rise to phasic contractions. ${ }^{19}$ The subtype of ICC responsible for SW generation are generally stellate in appearance and located predominantly in networks at the myenteric (ICC-MY) and submucosal (ICC-SM) surfaces of the circular muscle layer. A second subtype of ICC is located within the

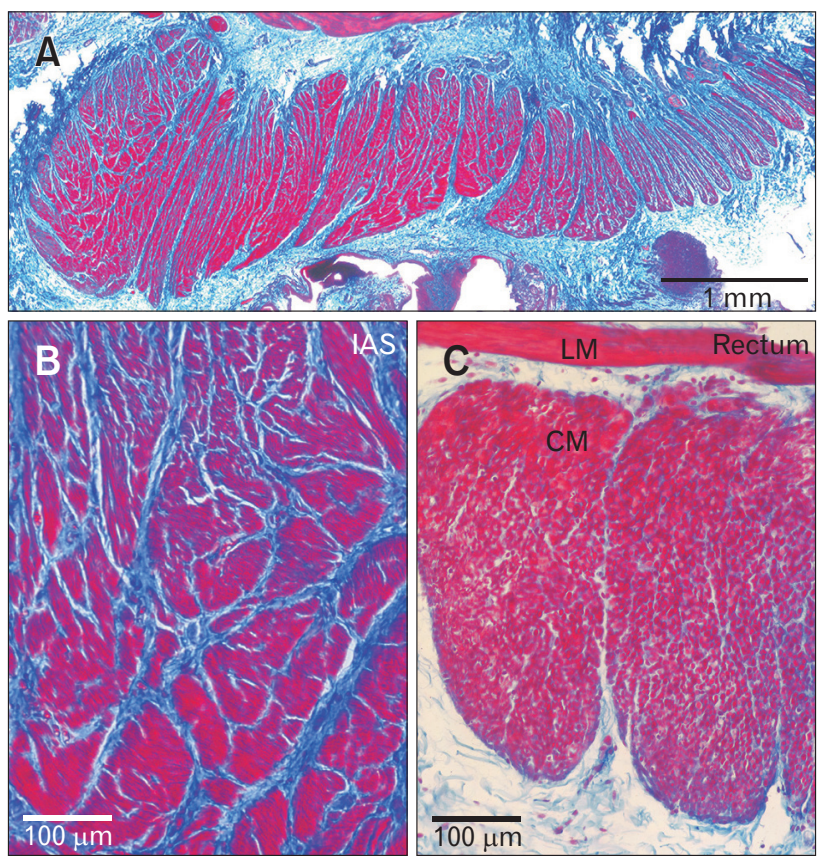

Figure 1. Morphology of the Cynomolgus monkey rectoanal region. (A-C) Comparison of the morphology of the smooth muscle bundles of the monkey internal anal sphincter (IAS) and rectum stained with Masson's trichrome (adapted from Cobine et $\mathrm{al}^{15}$ with permission). Smooth muscle is stained red/purple and connective tissue is stained blue. (A) Thin section of the distal most $5 \mathrm{~mm}$ of the gastrointestinal (GI) tract at low magnification. (B) Higher magnification image of the distal IAS. Many minibundles (red) separated by connective tissue septa (blue) are present. (C) Rectal bundles from another rectoanal preparation at the same magnification as (B). Entire circular muscle (CM) bundles as well as longitudinal muscle (LM) can be visualized since the rectum is thinner than the IAS. Less connective tissue is also present within and between rectal muscle bundles. 
circular and longitudinal muscle layers. These intramuscular ICC (ICC-IM) run parallel to SMCs and are generally spindle-shaped in morphology. ICC-IM are found in close association with nerves and have been shown to play an important role in excitatory and inhibitory neuromuscular transmission (NMT). ${ }^{20-22}$

\section{Interstitial Cells of Cajal in the Internal Anal Sphincter}

ICC have also been identified in the IAS of mouse, monkey, and humans with immunohistochemical techniques (Fig. 2A and 2C), ${ }^{15,23,24}$ and in the dog IAS with electron microscopy. ${ }^{14}$ In mouse, the volume occupied by ICC is estimated to be about $5 \%$ of the total circular muscle layer volume. ${ }^{23}$ There are significant differences in the morphology and localization of ICC in the IAS versus the large intestine. Whereas ICC-MY, ICC-IM, and ICC-SM are all represented in the rectum the density of ICC-MY and ICC-SM declines in the aboral direction leaving only ICC-IM in the distal IAS. Interestingly, the distal IAS is also where the largest and highest frequency SWs occur. ${ }^{16}$ The morphology of ICC-IM in dog and monkey also changes from spindle-shaped cells in the rectum to highly branched cells in the IAS (Fig. 2A and 2B). ${ }^{14,15}$ Since ICCMY and ICC-SM are absent from the IAS and the morphology of ICC-IM resembles that of other pacemaker ICC, we have hypothesized that ICC-IM are the pacemaker cells of the IAS. ${ }^{15}$ Recently, we have undertaken studies using the Kit-GCaMP3 ${ }^{+}$mouse; a transgenic mouse that expresses the $\mathrm{Ca}^{2+}$ sensitive fluorophore GCaMP3 in ICC-IM. These preliminary studies have identified whole cell $\mathrm{Ca}^{2+}$ transients in $\mathrm{GCaMP}^{+}$cells that are synchronized with adjacent $\mathrm{GCaMP}^{+}$cells. Furthermore, the frequency of $\mathrm{Ca}^{2+}$ transients in $\mathrm{GCaMP}^{+}$cells is equivalent to the frequency of SWs in the mouse IAS. ${ }^{25,26}$ These data provide additional evidence that ICC-IM are the pacemaker cells of the IAS.

\section{General Features of Platelet-derived Growth Factor Receptor $\alpha$-positive Cells}

A second population of interstitial cells has also been identified in the muscularis externa. These cells were originally described as "fibroblast-like cells" because they share a number of morphological features in common with true fibroblasts. ${ }^{27}$ However, since fibroblast-like cells highly express the receptor tyrosine kinase platelet-derived growth factor receptor $\alpha(\mathrm{PDGF} \alpha)$ they have now been assigned the name "PDGFR $\alpha^{+}$cells." ${ }^{\text {"28,29 }}$ SMCs, ICC, and PDGFR $\alpha^{+}$cells form gap junctions with one another and together they comprise the "SIP syncytium," ie, an arrangement that coordinates the electrical signals related to pacemaker activity and $\mathrm{NMT}^{29}$

\section{Platelet-derived Growth Factor Receptor $\alpha$-positive Cells in the Internal Anal Sphincter}

PDGFR $\alpha^{+}$cells are also present in the muscularis externa of the mouse and monkey IAS (Fig. 3). ${ }^{23,30}$ In mouse, the estimated volume occupied by PDGFR $\alpha^{+}$cells is about $15 \%$ of total muscle volume which is about $3 \times$ the volume occupied by ICC. ${ }^{23}$ Like monkey ICC-IM, the morphology of PDGFR $\alpha^{+}$cells changes from predominantly spindle-shaped cells in rectum to more stellateshaped cells in the IAS (Fig. 3). ${ }^{30}$
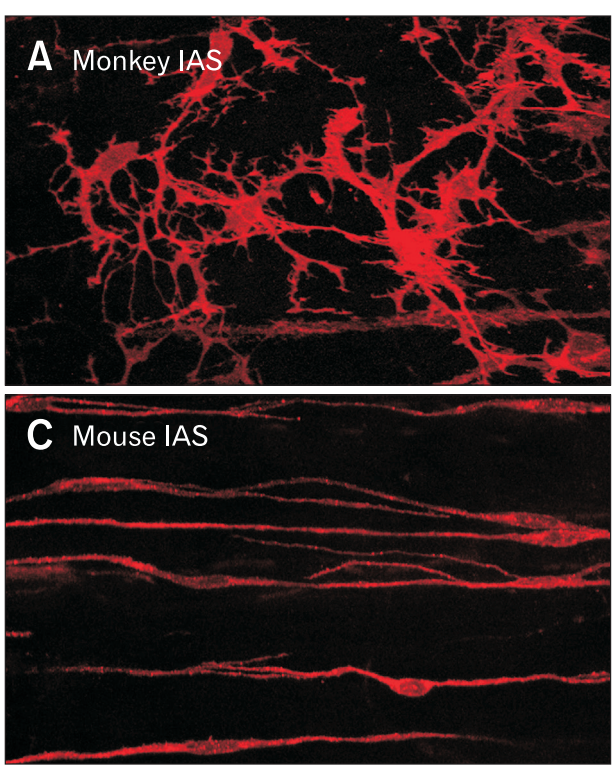
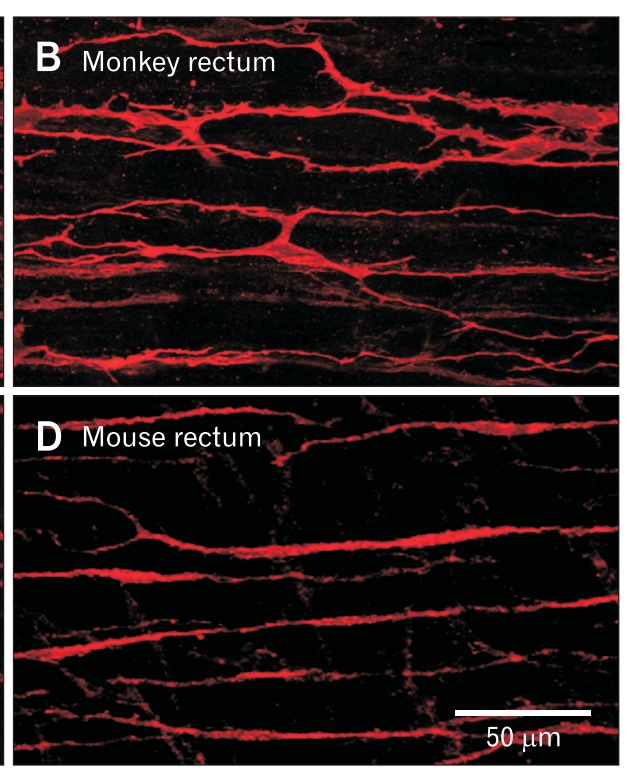

Figure 2. Immunohistochemical labeling of receptor tyrosine kinase $\mathrm{Kit}^{+}$ intramuscular interstitial cells of Cajal (ICC-IM) in the monkey and mouse rectoanal regions. (A) ICC-IM are highly branched stellate-shaped cells in the monkey internal anal sphincter (IAS) whereas (B) they are more spindleshaped in rectum and run parallel to smooth muscle cells (SMCs). (C, D) Intramuscular ICC also run parallel to SMCs in the wildtype mouse IAS and rectum but are spindle-shaped. While ICC-IM in monkey rectum (B) are less branched than in the monkey IAS (A), they are more branched than ICC-IM in the mouse IAS (C) and rectum (D). 


\section{Electrical and Contractile Properties of the Internal Anal Sphincter}

\section{Spontaneous Electrical Activity}

Membrane potential (Em) in the IAS is seldom quiescent. Rather, rhythmic oscillations in the Em occur that we refer to as SWs even though they do not share all of the properties described for SWs elsewhere in the GI tract. SWs were first identified in the cat IAS with sucrose gap techniques ${ }^{31}$ and later with microelectrode measurements in the dog, monkey, and mouse IAS (Fig. 4). ${ }^{16,32-35} \mathrm{SW}$ frequencies range from about 45-80 cpm in mouse $\mathrm{e}^{16,35,36}$ to about 15$30 \mathrm{cpm}$ in the dog and monkey IAS. ${ }^{33,34} \mathrm{SW}$ amplitude varies but rarely exceeds $30 \mathrm{mV}$. The SWs of the IAS differ in several ways from intestinal SWs. Importantly, IAS SWs are abolished by the L-type $\mathrm{Ca}^{2+}$ channel $\left(\mathrm{Cav}_{\mathrm{L}}\right)$ blocker nifedipine (Fig. 5A), whereas intestinal SWs are not (Fig. 5B). ${ }^{33,36,37}$ IAS SWs also lack the rapid upstroke that is characteristic of intestinal SWs (ie, 1-10 V/sec maximum $\mathrm{dV} / \mathrm{dt}$ for small intestine $\mathrm{e}^{37,38}$ versus $10-100 \mathrm{mV} / \mathrm{sec}$ maximum $\mathrm{dV} / \mathrm{dt}$ for the $\mathrm{IAS}^{35}$ ). The rapid $\mathrm{dV} / \mathrm{dt}$ of intestinal SWs is due to $\mathrm{T}$ type $\mathrm{Ca}^{2+}$ channels that activate at more negative voltages and are unaffected by $\mathrm{Cav}_{\mathrm{L}}$ blockers. ${ }^{39}$ Instead, IAS SWs reach peak depolarization approximately half way through the electrical event. In studies of the dog IAS, SW amplitude and frequency were found to be the same across the thickness of the circular muscle layer. Indeed, even isolated subsections of the muscle thickness had equivalent $\mathrm{SWs}^{33}$ suggesting that they arise throughout the muscle thickness. This behavior is in keeping with our hypothesis that ICC-IM are responsible for the generation of SWs since ICC-IM are also distributed throughout the muscle thickness.

Although the frequency and amplitude of SWs in the distal IAS is the same across the muscle thickness and around the circumference, both frequency and amplitude decline in the oral direction. ${ }^{16,32,33}$ Upon reaching the rectum electrical activity across the muscle thickness is no longer homogenous. Rather, SWs begin
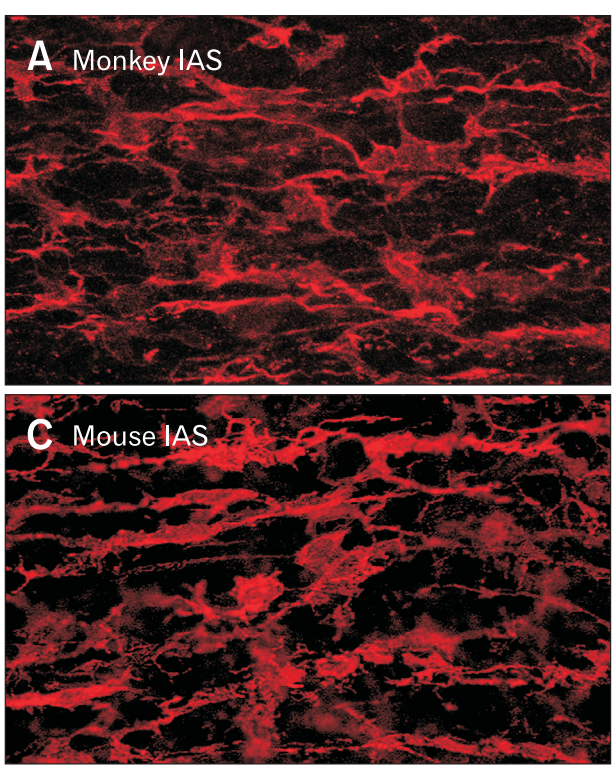
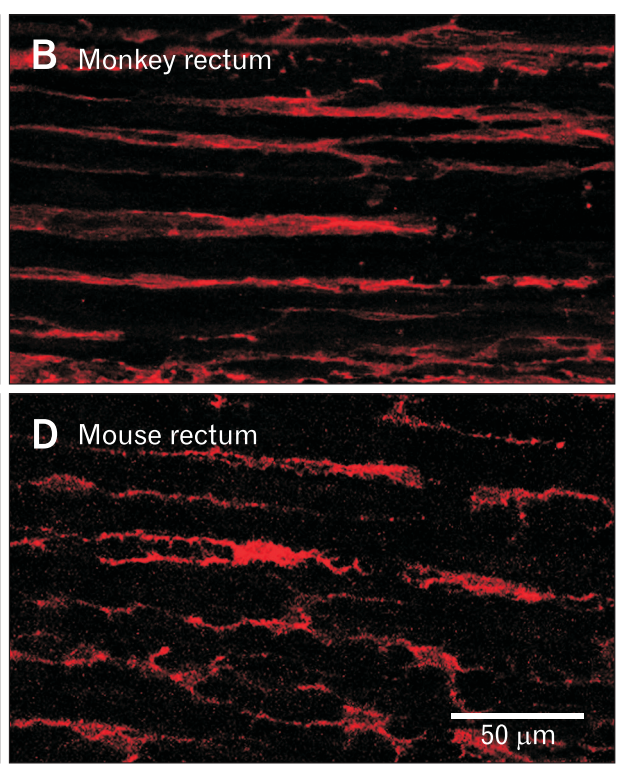

Figure 3. Immunohistochemical labeling of intramuscular platelet-derived growth factor receptor $\alpha$-positive $\left(\mathrm{PDGFR} \alpha^{+}\right)$cells in the monkey and mouse rectoanal regions. Intramuscular PDGFR $\alpha^{+}$cells run parallel to the smooth muscle cells (SMCs) and are highly branched stellate-shaped cells in the monkey (A) and mouse (C) internal anal sphincter (IAS). Intramuscular PDGFR $\alpha^{+}$cells also run parallel to $\mathrm{SMCs}$ in rectum but differ from the IAS in that they are more spindleshaped ( $\mathrm{B}$, monkey; $\mathrm{D}$, mouse).
A Mouse IAS

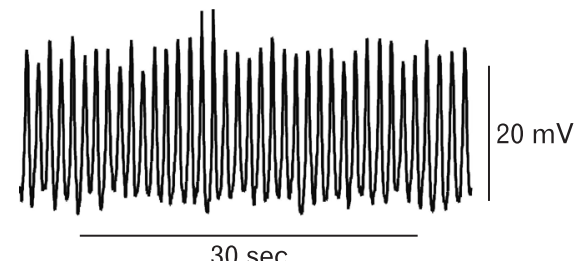

B Dog IAS

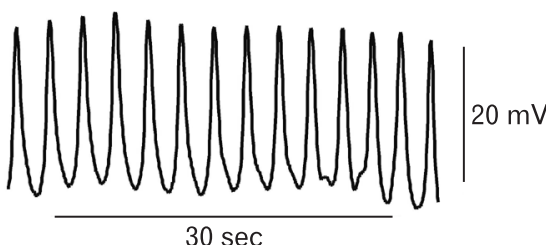

$30 \mathrm{sec}$
C Monkey IAS

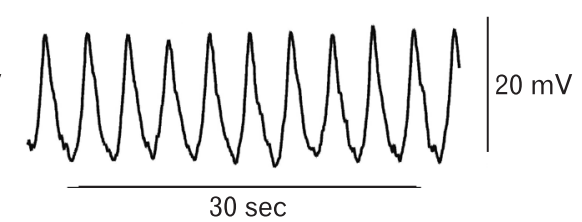

Figure 4. Slow wave (SW) activity in the mouse, dog, and monkey internal anal sphincter (IAS). Sample traces of SW activity recorded from the mouse (A), dog (B), and monkey (C) IAS. Note that the frequency of SWs is significantly higher in the mouse IAS. 
A IAS

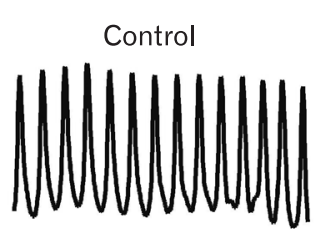

B Rectum

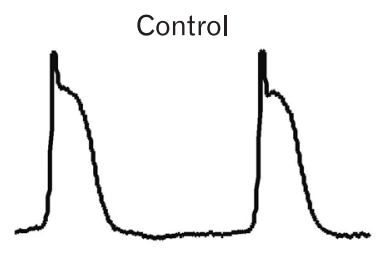

C IAS Nifedipine $1 \mu \mathrm{M}$
Nifedipine 8 min

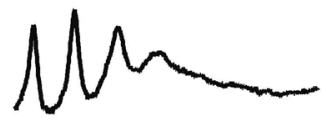

Nifedipine $5 \mathrm{~min}$

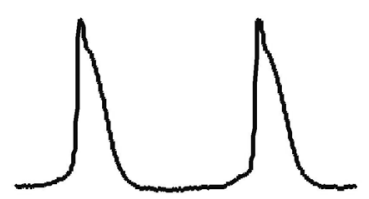

D Rectum
Nifedipine 15 min

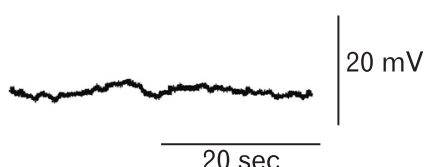

Nifedipine $20 \mathrm{~min}$

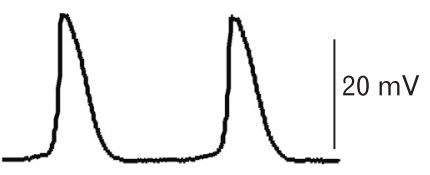

$20 \mathrm{sec}$

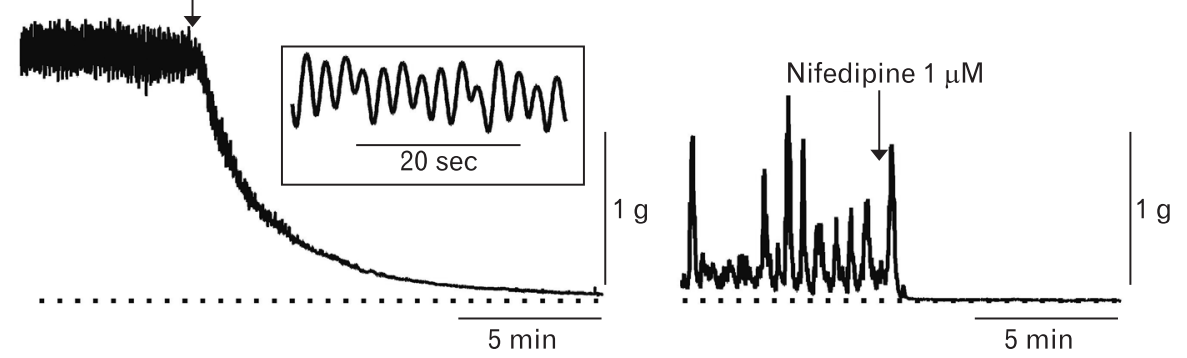

Figure 5. Effect of nifedipine on slow waves (SWs) and contractile activity in the dog and monkey rectoanal region. (A) Sample traces of SWs recorded from the dog internal anal sphincter (IAS) under control conditions (left trace) and at 8 minutes and 15 minutes following addition of nifedipine (middle and right traces). Nifedipine completely abolished SWs after 15 minutes. (B) Sample traces of SWs recorded from the submucosal side of the circular muscle in the dog rectum under control conditions (left trace) and at 5 minutes and 20 minutes following addition of nifedipine (middle and right traces). SWs were not abolished by nifedipine but upstroke velocity and duration were decreased. (A) and (B) are adapted from Mutafova-Yambolieva et $\mathrm{al}^{33}$ with permission. Sample traces of the contractile activity recorded from the monkey IAS (C) and rectum (D) before and after addition of nifedipine. Dotted line indicates zero active contraction. Contractile activity in the IAS consisted of phasic contractions superimposed upon tone. Inset shows phasic contractions at a faster sweep speed (C). Contractile activity in the rectum was predominantly phasic (D). Nifedipine abolished tone and phasic contractions in both muscles (C, D).

to appear at the submucosal edge that resemble those previously described for the dog and human colon. ${ }^{40,41}$ These changes in SW properties in rectum correspond to the gradual appearance of ICCSM that have been identified with immunohistochemical techniques. $^{15}$

In addition to differences in SWs between the IAS and rectum there are also differences in the level of Em reached between SWs which we shall refer to as "resting Em." In the IAS, resting Em ranges from -43 to $-49 \mathrm{mV}$ whereas in the rectum it is significantly more negative, ie, $5 \mathrm{mV}$ gradient in mouse, ${ }^{16} 20 \mathrm{mV}$ gradient in dog, ${ }^{33}$ and $7 \mathrm{mV}$ gradient in monkey. ${ }^{30}$ There is evidence that anoctamin-1 (ANO1) currents in ICC-IM contribute to this depo- larized Em. ${ }^{70}$ The gradual hyperpolarization of Em in the proximal direction is one reason why contractile activity transitions from tone generation in the IAS to predominantly phasic contractions in the rectum.

\section{Relationship Between Electrical and Contractile Activity}

In addition to tone, the IAS also exhibits phasic contractions (Fig. 5C and 6A) and SWs (Fig. 4, 5A, and 6B). Thus, the conventional description of the IAS as a "purely tonic muscle" requires revision. Rather, the IAS is a phasically active muscle that generates tone. Tone is greatest at the distal end of the IAS where 
A IAS contraction

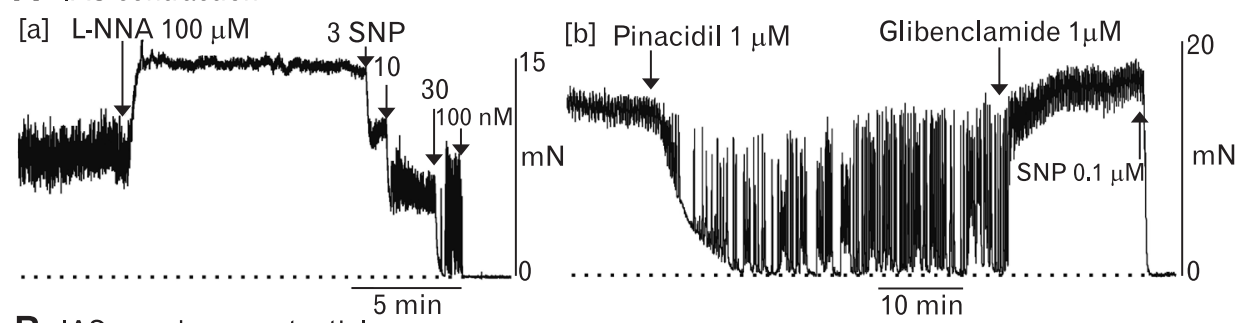

B IAS membrane potential

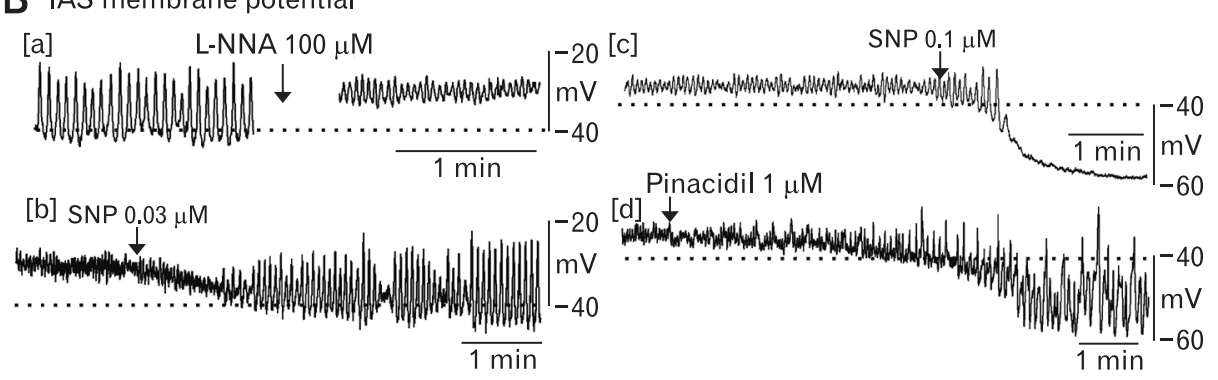

Figure 6. Changes in contractile and electrical activity in the Cynomolgus monkey internal anal sphincter (IAS) after application of various drugs. (A) Sample traces of contractile activity in the monkey IAS. [a] Tone and phasic activity were observed under control conditions. Following NOS blockade with $\mathrm{N} \omega$-Nitro-L-arginine (L-NNA; $100 \mu \mathrm{M})$ the amplitude of tone increased while phasic contractile amplitude decreased. This effect was reversed with 3-30 nM sodium nitroprusside (SNP) while the highest concentration of SNP (100 nM) abolished contraction. [b] Contractile activity in another muscle segment in the presence of L-NNA. The actions of $1 \mu \mathrm{M}$ pinacidil were similar to those of $30 \mathrm{nM}$ SNP and were reversed by $1 \mu \mathrm{M}$ glibenclamide. Subsequent addition of SNP (100 nM) abolished all contractile activity. (B) Sample traces of electrical activity in the monkey IAS. [a] Slow waves (SWs) were present in the monkey IAS under control conditions (left). After addition of L-NNA membrane potential (Em) depolarized and SW amplitude was reduced (right). [b] Different microelectrode recording in the presence of L-NNA. SW activity was restored following addition of $30 \mathrm{nM}$ SNP. [c] Different microelectrode recording in the presence of L-NNA. SNP (100 nM) resulted in a transient period of larger amplitude SWs followed by further hyperpolarization and blockade of SWs. [d] Different microelectrode recording in the presence of L-NNA. Pinacidil $(1 \mu \mathrm{M})$ caused hyperpolarization and the return of SWs. ${ }^{34}$ Higher concentrations of pinacidil abolished contraction as well as SWs (data not shown).

SW frequency and amplitude are greatest. ${ }^{16,33}$ In subsequent sections we describe 2 mechanisms capable of giving rise to tone through summation of phasic events. Contraction and SWs in the IAS are highly sensitive to blockade of $\mathrm{Cav}_{\mathrm{L}}$ channels with dihydropyridines such as nifedipine (Fig. 5A and 5C) or to drugs that hyperpolarize $\mathrm{Em}$ such as the $\mathrm{K}_{\mathrm{ATP}}$ channel opener pinacidil (Fig. 6Ab, Bd) and the NO-donor sodium nitroprusside (SNP, Fig. $6 \mathrm{Aa}, 6 \mathrm{Bb}$, and $6 \mathrm{Bc}){ }^{30,34,43-46}$ Thus electromechanical coupling mechanisms clearly play an important role in regulating IAS motility.

\section{Effect of Tonic Nitrergic Activity on Electrical and Contractile Activity}

Spontaneous contractile activity in many GI muscles is subject to strong tonic nitrergic inhibition. ${ }^{45,4-51}$ This is particularly evident in the monkey IAS in vitro which exhibits large phasic contractions superimposed upon tone when nitric oxide synthase (NOS) activity is present. ${ }^{15,30,44}$ Following NOS blockade with N $\omega$-Nitro-
L-arginine (L-NNA) tone increases while phasic contractile amplitude decreases (Fig. 6Aa). NOS inhibition also depolarizes Em and decreases SW amplitude (Fig. 6Ba). Thus, the increased tone accompanying NOS blockade is likely due, at least in part, to an increase in $\mathrm{Ca}^{2+}$ entry via $\mathrm{Cav}_{\mathrm{L}}$ window current ${ }^{52-54}$ as further discussed in a later section. $\mathrm{NO}$ also directly inhibits $\mathrm{Cav}_{\mathrm{L}}{ }^{55,56}$ and enhances $\mathrm{Ca}^{2+}$ uptake into intracellular stores ${ }^{57,58}$; effects that are relieved by NOS inhibition. Finally, NO can decrease myofilament sensitization $^{59-61}$; an action that is also relieved by NOS inhibition.

The effects of NOS blockade on contraction, Em and SWs are all reversed with low concentrations of the NO-donor SNP (Fig. 6Aa and 6Bb) or with pinacidil (Fig. 6Ab and 6Bd). Higher concentrations of SNP abolish contraction along with producing greater hyperpolarization and loss of SWs (Fig. 6Aa and 6Bc). These effects are also mimicked by higher concentrations of pinacidil (data not shown). Thus, pure tonic contraction occurs when Em is sufficiently depolarized to generate $\mathrm{Cav}_{\mathrm{L}}$ window current without SWs while contraction is abolished when Em is hyperpolarized be- 
low the activation threshold for $\mathrm{Cav}_{\mathrm{L}}$; an action that also eliminates SWs. Between these extremes is a range of Em where tone, phasic contractions and SWs are all present. ${ }^{34}$ Thus motility in the IAS is highly dependent upon Em. Since nerves produce large rapid changes in Em (ie, junction potentials), they are ideally suited for moment to moment adjustments in IAS motility.

\section{Role of Chloride Channels in Electrical and Contractile Activity}

Chloride ion $\left(\mathrm{Cl}^{-}\right)$channels have long been proposed as contributors to resting $\mathrm{Em}$ in the smooth muscle. ${ }^{62}$ More recently it has been shown that intestinal ICC express ANO1, a $\mathrm{Ca}^{2+}$ activated $\mathrm{Cl}^{-}$channel, at far greater levels than SMCs. ${ }^{63-66}$ There is now substantial evidence that ANO1 in ICC plays a central role in the generation of SWs. Briefly, intermittent release of $\mathrm{Ca}^{2+}$ from the endoplasmic reticulum in pacemaker ICC results in activation of ANO1 and spontaneous transient inward currents (STICs). The intermittent depolarizations generated by STIC activity then activate voltage dependent $\mathrm{Ca}^{2+}$ channels resulting in a full blown $\mathrm{SW}^{63,64,67-69}$

Since our hypothesis is that ICC-IM are responsible for SW generation in the IAS, experiments were undertaken to determine whether ANO1 also contributes to the electrical and contractile activity of the mouse IAS. These studies revealed that: (1) Ano1 gene expression is 26x greater in ICC-IM than in SMCs, (2) ANO1 protein expression is resolvable in ICC but not in SMCs, and (3) ANO1 antagonists abolished SWs, phasic contractions and tone as well as causing a small hyperpolarization of resting $\mathrm{Em}$. These data suggest that ANO1 in ICC plays a central role in the generation of SWs and contractile activity in the IAS. ${ }^{70}$

\section{Tone Generation in the Internal Anal Sphincter}

Historically, tone has been attributed to contractile mechanisms arising directly from the $\mathrm{SMCs}$, ie, myogenic activity. However, as introduced above, there is increasing evidence that ICC participate in tone generation in the IAS. In this section we explore four different mechanisms that may give rise to tone in the IAS. Three of these are critically dependent upon electromechanical coupling and $\mathrm{Cav}_{\mathrm{L}}$ activity, whereas the fourth (ie, myofilament sensitivity) is not.

\section{Summation of Asynchronous Phasic Activity}

Skeletal postural muscles can maintain tone over extended periods of time. ${ }^{71}$ Tone in these muscles is achieved through the sum- mation of contractile activity associated with asynchronous firing of motor units. It is possible that a similar mechanism contributes to tone generation in the IAS. An important difference however is that the equivalent "motor unit" in the IAS is a minibundle with SMCs electrically coupled to one another but electrically isolated from neighboring bundles. This description differs somewhat from the classic definition of smooth muscles as either "single unit" (all cells electrically coupled to neighbors) or "multiunit" (each cell electrically isolated from its neighbors), but it is appropriate for the GI tract where most muscles fall somewhere in between these two extremes. As described in the previous section, pacemaker activity is distributed across the thickness of the IAS, indicating that each minibundle is electrically active. If adjacent minibundles are poorly coupled and independently driven by pacemaker cells, then tone may arise through summation of asynchronous activity. To date this hypothesis has not been tested in the IAS of a large animal such as dog or monkey. However, one study ${ }^{16}$ has been completed in the mouse IAS which is composed of far fewer minibundles (ie, 5-8) each separated by thin connective tissue septa. Dual microelectrode recordings revealed declining SW "coordination" (defined as a constant phase relationship between $\mathrm{SWs}$ ) as electrode separation was increased. Thus, only $40 \%$ of SWs were coordinated when the oral/ anal electrode separation was $0.25 \mathrm{~mm}$ (ie, a few minibundles) while significantly greater coordination was observed in the long axis of SMCs (ie, $40 \%$ at $1 \mathrm{~mm}$ ) (Fig. 7A). However, even $1 \mathrm{~mm}$ still amounts to less than $15 \%$ of the intact IAS circumference. Thus, even in the mouse IAS, the circular muscle layer did not behave strictly as a "single unit" but rather as a composite of minibundles that were only loosely coupled to one another. ${ }^{16}$ The contractions generated by such asynchronous activity is predicted to raise tone in the muscle.

\section{Partial Tetanus}

Tone can also occur in skeletal muscle when the frequency of stimulation is so high that contraction ceases to return to baseline between stimuli. This phenomenon is referred to as "partial (incomplete) tetanus" and it is due to the inability of $\mathrm{Ca}^{2+}$ removal to keep up with $\mathrm{Ca}^{2+}$ delivery resulting in increased basal cytoplasmic $\left[\mathrm{Ca}^{2+}\right]{ }^{72}$ Contractile activity in the IAS resembles partial tetanus in that phasic contractions are superimposed upon tone. To investigate whether a "partial tetanus" type mechanism might contribute to tone generation we examined $\mathrm{Ca}^{2+}$ transients in the IAS of a transgenic mouse that expresses the $\mathrm{Ca}^{2+}$ sensitive fluorophore GCaMP3 in SMCs (SM-GCaMP3; Fig. 7B). The frequency of $\mathrm{Ca}^{2+}$ transients in $\mathrm{GCaMP}^{+}$cells $(70-80 \mathrm{cpm})$ was equivalent 

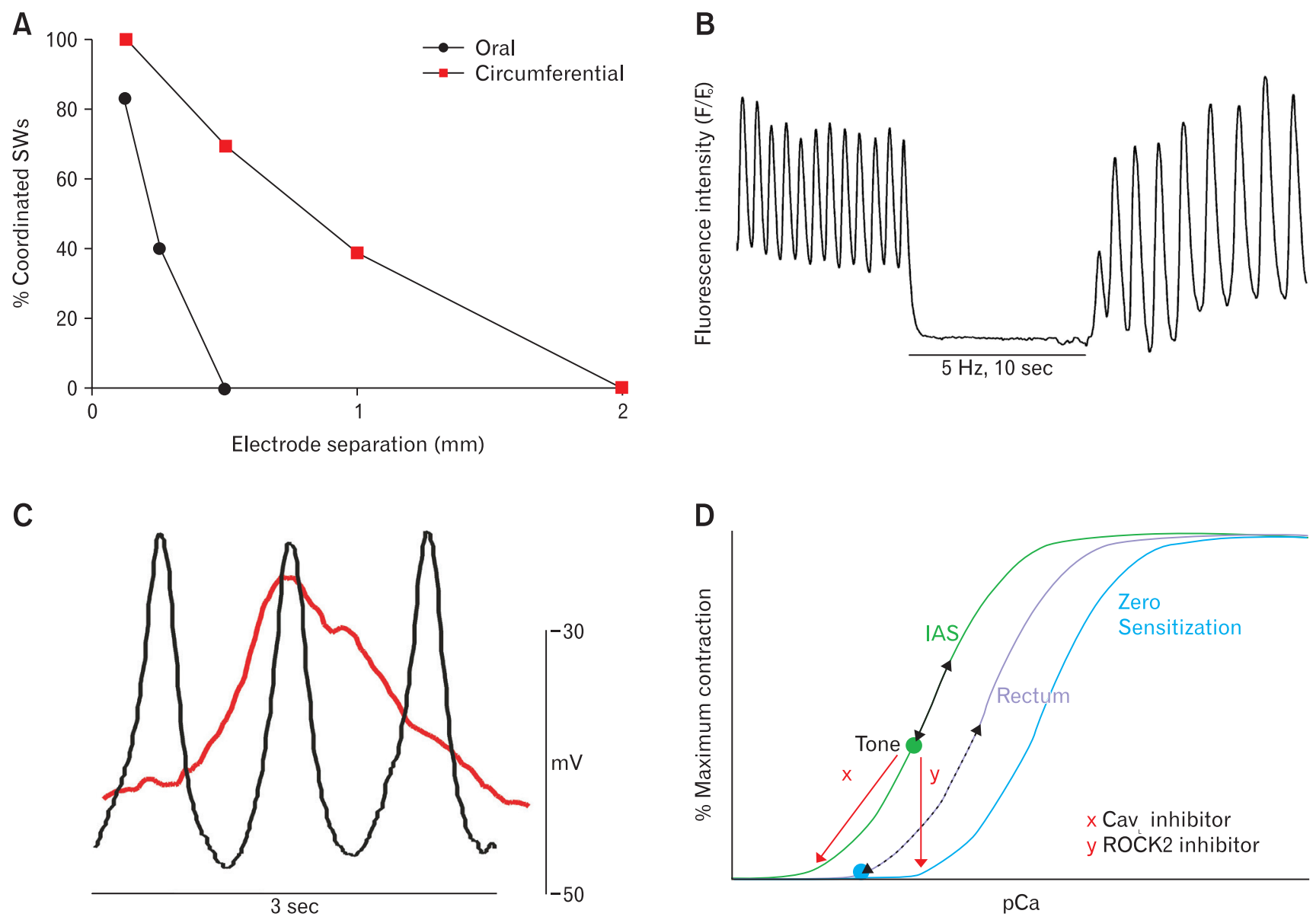

Figure 7. Examples of electromechanical coupling behaviors in the internal anal sphincter (IAS; A-C) that give rise to tone and their possible relationship to myofilament sensitization (D). (A) Summation of asynchronous phasic activity. Microelectrode studies in the mouse IAS reveal significantly greater coordination of slow waves (SWs) in the circumferential (red squares) than in the oral (black circles) direction indicating that the IAS does not behave as a "single unit." Instead, asynchronous (aka uncoordinated) phasic activity is present that will sum to generate tone (adapted from Hall et $\mathrm{al}^{16}$ with permission). (B) Partial tetanus. Calcium imaging studies in the SM-GCaMP3 mouse IAS reveal high frequency $\mathrm{Ca}^{2+}$ transients (fluorescence intensity) at the SW frequency $(75 \mathrm{cpm})$. When contraction is abolished with electrical field stimulation (EFS) of nerves ${ }^{125}$ cytoplasmic $\mathrm{Ca}^{2+}$ declines significantly indicating that it is normally elevated when tone is present. These data ${ }^{26,73}$ support a partial tetanus-type mechanism as described in the text. (C) Window current. Superimposed SW recordings from the mouse (black) and monkey (red) IAS reveal that while SW frequency is greater in the mouse membrane potential $(\mathrm{Em})$ remains depolarized over a greater period of time in monkey. These conditions result in greater window current in monkey that will contribute to tone development. (D) Myofilament sensitization. Cartoon depicting the possible relationship between myofilament sensitization, electromechanical coupling and contraction in the IAS and rectum. Plotted is percent maximum contraction as a function of intracellular $\mathrm{Ca}^{2+}$ concentration ( $\mathrm{pCa}$ ) for the IAS (left), rectum (middle), and for zero myofilament sensitization (right). The IAS curve is to the left of rectum because of greater myofilament sensitization. ${ }^{42}$ pCa remains elevated in the IAS (green dot) since resting Em is more depolarized and SW frequency is greater than in rectum. ${ }^{16,33}$ Elevated pCa will give rise to tone. Fluctuations in pCa above the green dot with each SW (black arrow, left curve) will result in phasic contractions superimposed upon tone. The overall fluctuations in $\mathrm{pCa}$ in the tissue will be dampened by asynchronous activity in adjacent muscle bundles. The $\mathrm{pCa} /$ contraction curve for rectum is depicted to the left of zero sensitization since there is also some myofilament sensitization in rectum. ${ }^{91}$ pCa between SWs in rectum (blue dot, middle curve) is less than in the IAS (green dot, left curve) because resting Em is more negative and SWs occur at a lower frequency. With each SW, pCa transiently rises (dashed arrow, middle curve) generating a phasic contraction. Tone can develop in the rectum if depolarization is sustained (eg, elevation of extracellular potassium concentration $\left.{ }^{78}\right)$. Blockade of $\mathrm{L}$-type $\mathrm{Ca}^{2+}$ channel $\left(\mathrm{Cav}_{\mathrm{L}}\right)$-dependent $\mathrm{Ca}^{2+}$ entry $($ eg, nifedipine $[\mathrm{x}])$ decreases $\mathrm{pCa}$ and abolishes contraction in both muscles. In contrast, blockade of Rho-associated protein kinase 2 (ROCK2) activity (eg, Y27632 [y]) shifts the pCa/ contraction curve of both muscles toward zero sensitization, again abolishing (or greatly diminishing) contraction. 
to the SW frequency suggesting that $\mathrm{Ca}^{2+}$ transients are initiated by SWs. The $\mathrm{Ca}^{2+}$ removal rate was estimated by determining the time constant ( $\tau=0.4-0.5$ seconds) for the decline of $\mathrm{Ca}^{2+}$ following transient peaks. Importantly, we also found that the level of intracellular $\mathrm{Ca}^{2+}$ between transients was significantly greater than in the absence of contraction. Thus, the rate of $\mathrm{Ca}^{2+}$ removal was insufficient to return $\mathrm{Ca}^{2+}$ to non-contractile levels before the arrival of the next $\mathrm{Ca}^{2+}$ transient, suggesting a partial tetanus-type mechanism, ie, an inability of cells to clear or sequester $\mathrm{Ca}^{2+}$ between rapid frequency voltage-dependent $\mathrm{Ca}^{2+}$ entry events (ie, $\mathrm{SWs}$ ). ${ }^{26,73}$

\section{Window Current}

$\mathrm{Cav}_{\mathrm{L}}$ play a central role in delivering $\mathrm{Ca}^{2+}$ to the cytoplasm for IAS contraction. ${ }^{44}$ Both the activation and inactivation of $\mathrm{Cav}_{\mathrm{L}}$ are voltage dependent processes with maximum current occurring around $0 \mathrm{mV}$ and threshold current appearing around -50 to -45 $\mathrm{mV}$. Between these extremes sustained $\mathrm{Ca}^{2+}$ entry can occur since $\mathrm{Cav}_{\mathrm{L}}$ are activated and inactivation is incomplete. This sustained current is referred to as "window current" ${ }^{52-54,74-76}$ and has long been associated with the sustained contraction that occurs in blood vessels upon exposure to a depolarizing concentration of extracellular potassium $\left(\left[\mathrm{K}^{+}\right]_{0}\right){ }^{77}$ Likewise, exposure of the phasically active dog gastric antrum to a depolarizing concentration of $\left[\mathrm{K}^{+}\right]_{0}$ results in tone generation. ${ }^{78}$ Resting Em in the IAS is more depolarized than intestine, placing it nominally within the range of window current. Thus $\mathrm{Cav}_{\mathrm{L}}$ window currents associated with the depolarized level of resting $\mathrm{Em}$ in the IAS likely contributes to tone generation.

The frequency of SWs in the dog and monkey IAS is significantly lower than in the mouse IAS (Fig. 4). However, the rate of SW depolarization and repolarization is also lower (Fig. 7C). For this reason, Em remains significantly above the threshold for activation of $\mathrm{Cav}_{\mathrm{L}}$ channels for a longer period of time. Under these circumstances both time dependent and -independent (ie, window current) processes will contribute to $\mathrm{Ca}^{2+}$ entry. Prolonged depolarization and $\mathrm{Ca}^{2+}$ entry therefore are likely to play a more important role in tone development in the dog and monkey IAS than a partial tetanus-type mechanism. Indeed, when NOS activity is blocked in the monkey IAS, Em depolarizes, and SWs are largely eliminated (Fig. 6B). Under these conditions, window current becomes the only electromechanical coupling mechanism associated with tone development.

\section{Myofilament Sensitivity}

The final mechanism to be considered for tone generation in the IAS is enhanced sensitivity of the myofilaments to $\mathrm{Ca}^{2+}$. Smooth muscle contraction occurs when the $20-\mathrm{kD}$ regulatory light chain of myosin $\left(\mathrm{MLC}_{20}\right)$ is phosphorylated. The degree of contraction therefore depends upon a balance between the activities of myosin light chain kinase which phosphorylates $\mathrm{MLC}_{20}$ and myosin light change phosphatase (MLCP) which dephosphorylates $\mathrm{MLC}_{20}$. MLCP consists of a catalytic subunit (protein phosphatase 1 , or PP1) and a regulatory subunit (myosin phosphatase target subunit 1, or MYPT1). MYPT1 facilitates the ability of PP1 to dephosphorylate $\mathrm{MLC}_{20}$ thereby terminating contraction. When MYPT1 is phosphorylated it no longer facilitates $\mathrm{PP} 1, \mathrm{MLC}_{20}$ remains phosphorylated and contraction persists. Thus, pathways that increase MYPT1 phosphorylation increase the amount of contraction occurring for a given level of intracellular $\mathrm{Ca}^{2+}$, ie, myofilament sensitization. ${ }^{79-86}$ An important regulator of MYPT1 phosphorylation is Ras homolog gene family, member A (RhoA). Activation of RhoA leads to activation of Rho-associated protein kinase 2 (ROCK2) which then phosphorylates MYPT1.

The most comprehensive examination of the RhoA/ROCK2/ MYPT1 $\mathrm{Ca}^{2+}$ sensitization pathway in the IAS are studies of rat and human GI muscles by Rattan and coworkers. ${ }^{87-90}$ Specifically, these investigators reported that: (1) RhoA, ROCK2, and MYPT1 phosphorylation levels were greater in IAS than in the rectum, (2) ROCK2 antagonists abolished MYPT1 phosphorylation as well IAS contraction, and (3) the potency of ROCK2 antagonists in blocking contraction was significantly greater in the IAS than in the rectum. From these data the authors concluded that tone in the IAS was due to greater $\mathrm{Ca}^{2+}$ sensitization via the RhoA/ROCK2/ MYPT1 pathway. We have repeated these experiments in the monkey IAS and the rectum. Our results are in general agreement with those of Rattan and Singh, ${ }^{90}$ in that western blot measurements revealed greater MYPT1 phosphorylation and ROCK2 expression in the IAS than in the rectum. In contrast, only small differences were noted in the potency of ROCK2 inhibitors between muscles. ${ }^{91}$ It is important to recognize that the differences in myofilament sensitivity occurring in the IAS and rectum are relative rather than absolute. Furthermore, as noted previously, contraction in both muscles is highly sensitive to $\mathrm{Cav}_{\mathrm{L}}$ inhibitors (Fig. $5 \mathrm{C}$ ). Thus, electromechanical mechanisms and myofilament sensitivity represent interrelated properties that together determine the final pattern of contraction in both muscles. A cartoon of these interactions is shown in Figure 7D. 


\section{Control of Motility in the Internal Anal Sphincter by Nerves}

The IAS is innervated by both excitatory and inhibitory motor neurons that can profoundly affect smooth muscle contraction. A unique aspect of this innervation is that a plexus of nerves is absent from the IAS myenteric surface ie, the site at which the cell bodies of motor neurons are typically located. None-the-less, both varicose neuronal NOS (nNOS) ${ }^{+}$and tyrosine hydroxylase $\left(\mathrm{TH}^{+}\right)$neurons are present throughout the thickness of the circular muscle layer. The available evidence suggests that the cell bodies of $\mathrm{nNOS}^{+}$neurons are located in more proximal GI regions, whereas the cell bodies of $\mathrm{TH}^{+}$neurons arise extrinsically. In this section we review the predominant excitatory and inhibitory motor pathways identified that regulate IAS motility.

\section{Excitatory Motor Innervation}

Excitatory motor innervation to the IAS of non-rodent species is sympathetic ${ }^{4,44,92-94}$ whereas in the intestine sympathetic nerves serve a neuromodulatory role. ${ }^{95,96}$ Postganglionic sympathetic neurons originate in the inferior mesenteric ganglion or pelvic plexus and travel to the IAS via lumbar colonic nerves, hypogastric nerves, or branches of the pelvic plexus. ${ }^{7,97,98}$ Cutting the hypogastric nerve and/or lumbar colonic nerve as well as high spinal anesthesia reduces IAS contraction, whereas stimulation of sympathetic nerve trunks increases contraction. ${ }^{4,99-106}$ These data support an excitatory role for sympathetic nerves in the IAS. As described in the previous sections, sympathetic nerves are not essential for tone generation in the IAS. However, given the strength of this motor pathway (eg, sympathetic nerves at least double contraction in vitro in the monkey IAS $^{15,44}$ ) they likely assist in maintaining or elevating anal pressure under some circumstances.

In keeping with the functional properties of sympathetic nerves described above, morphological studies have identified varicose $\mathrm{TH}^{+}$fibers throughout the IAS circular muscle layer at densities exceeding those of the rectum ${ }^{15,103,107}$ where motor innervation is

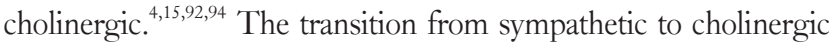
motor innervation in the dog rectoanal region is accompanied by a gradient in the contractile response to exogenously applied neurotransmitters. Thus, norepinephrine is most efficacious in the distal IAS and acetylcholine is least efficacious. The reverse is true for the proximal rectum. Furthermore, these differences in agonist efficacy are accompanied by corresponding gradients in adrenergic $\alpha 1$ and muscarinic receptor densities from the IAS to the rectum. ${ }^{92}$ Other studies of the pig, sheep and human IAS have shown that $\alpha 1 \mathrm{~A}$ receptors are the predominant receptor subtype underlying adrenergic contractile responses along with $\alpha 1 \mathrm{~L}$ and $\alpha 2 \mathrm{D} .{ }^{17,108,109}$

\section{Inhibitory Motor Innervation}

The IAS is also innervated by inhibitory motor neurons. These nerves participate in relaxation of the IAS during the rectoanal inhibitory reflex (RAIR) and during defecation. ${ }^{110-112}$ The RAIR is initiated when feces distend the rectum resulting in sensory feedback and a transient decrease in anal pressure associated with relaxation of the IAS. This is rapidly followed by contraction of the EAS and puborectalis to prevent unwanted passage of fecal contents through the anal canal, mitigating the reduction in anal pressure. ${ }^{113,114}$ With further distension of the rectum, the degree of response as well as the urge to defecate increases. ${ }^{114,115}$ When an appropriate time for defecation arrives, the IAS, EAS, and puborectalis all relax allowing feces to be expelled through the anal canal. ${ }^{116}$

Nitrergic nerves have been demonstrated to play a role in the relaxation of the IAS following rectal distension. ${ }^{117,118}$ It should be noted however that a vasoactive intestinal peptide (VIP) mediated neural pathway (VIPergic) is also likely to play a role since VIP is a major inhibitory neurotransmitter in the IAS. ${ }^{30,119-122}$ The contributions of nitrergic, purinergic, and VIPergic inhibitory pathways along with their signaling pathways are described below.

\section{Nitrergic Inhibitory Motor Innervation}

Nitric oxide (NO) plays a prominent role in inhibitory NMT in the IAS of all species studied including man. ${ }^{15,45,93,123-125}$ Although the IAS lacks a myenteric plexus there are numerous varicose nicotinamide adenine dinucleotide phosphate/nNOS neurons located within the circular muscle layer. ${ }^{15,16}$

Since first proposed in 1996, a number of studies have provided evidence that ICC-IM participate in nitrergic NMT in GI muscles. ${ }^{20,21,126}$ ICC-IM in these studies were long, spindle shaped cells (eg, stomach and intestine) that were closely associated with nNOS $^{+}$neurons. On the other hand, ICC-IM in the monkey IAS are highly branched cells that have only limited association with nNOS $^{+}$neurons (ie, $8 \%$ close association). ${ }^{15}$ Thus, it is presently unclear whether ICC-IM in the monkey IAS participate in nitrergic NMT. In contrast, the morphology of ICC-IM in the mouse IAS (Fig. 2C) and the degree of association between these cells and $\mathrm{nNOS}^{+}$neurons is very similar to that described for stomach and intestine. ${ }^{23}$ Furthermore, nitrergic inhibitory junction potentials (IJPs) are reduced in the $W / W^{V}$ mouse $I A S,{ }^{35}$ ie, an animal with reduced $\mathrm{Kit}^{+}{ }^{+} \mathrm{ICC}-\mathrm{IM}{ }^{127}$ Consequently, a stronger case exists for 
the participation of ICC-IM in nitrergic NMT in the mouse IAS.

Studies of nitrergic NMT in the mouse IAS suggest that multiple second messenger pathways and post-junctional effector cells are involved. ${ }^{125}$ Curiously, guanylate cyclase protein expression levels were greatest in PDGFR $\alpha^{+}$cells, even though no role has yet been established for PDGFR $\alpha^{+}$cells in nitrergic NMT. In contrast, cGMP-dependent protein kinase (PKG) expression levels were greatest in SMCs. Since the guanylate cyclase inhibitor $1 \mathrm{H}-$ $[1,2,4]$ Oxadiazolo [4,3-a] quinoxalin-1-one (ODQ) greatly diminished nitrergic NMT, it suggests that cGMP plays a fundamental role in transmission; a conclusion supported by other studies. ${ }^{128,129}$ However, nitrergic NMT was only partially reduced in the Prkg knockout mouse. Cyclic GMP is known to modulate other protein targets such as cAMP dependent protein kinase, cGMP-gated channels, and phosphodiesterases (ie, PDE3). ${ }^{130-132}$ Thus nitrergic NMT likely involves PKG-dependent as well as one or more PKG-independent pathways.

As discussed previously, the IAS is under significant tonic nitrergic inhibition that reduces contractile activity because of effects upon electromechanical coupling and myofilament sensitization. For this reason, it is extremely important to consider the status of neural activity before reaching any conclusion with regard to the contribution of either type of mechanism in the regulation of IAS motility in vivo. For example, studies undertaken in the presence of NOS inhibitors over-estimate myofilament sensitization since NO reduces MYPT1 phosphorylation, thus restoring MLCP activity. ${ }^{59,60,133-136}$ The absence of $\mathrm{NO}$ also results in a shift in electromechanical coupling away from phasic electrical events toward greater window current (eg, Fig. 6).

\section{Purinergic Inhibitory Motor Innervation}

Purinergic NMT is an additional neural pathway contributing to inhibitory NMT in the GI tract. ${ }^{137}$ Purines released from inhibitory motor neurons activate P2Y1 receptors ${ }^{138,139}$ located on a unique population of intramuscular PDGFR $\alpha^{+}$cells that are closely associated with inhibitory motor neurons. ${ }^{23,28,140}$ The binding of purines to $\mathrm{P} 2 \mathrm{Y} 1$ receptors on PDGFR $\alpha^{+}$cells leads to $\mathrm{Ca}^{2+}$ release from the endoplasmic reticulum followed by activation of small conductance $\mathrm{Ca}^{2+}$ - activated potassium (SK3) channels, generation of an IJP and contractile inhibition. ${ }^{28,29,141-143}$ Numerous studies have characterized purinergic NMT in the IAS of rodents. ${ }^{35,36,45,144}$ However, the limited evidence available from studies of the human IAS suggests that purinergic NMT is absent. ${ }^{124}$ Likewise, purinergic NMT is absent from the monkey IAS. ${ }^{30}$ Functional studies of the monkey IAS in concert with gene and protein expression measurements of nNOS, PDGFR $\alpha, \mathrm{P} 2 \mathrm{Y} 1$ receptors, and SK3 channels suggest that purinergic NMT is absent from the monkey IAS because of poor coupling between P2Y1 receptors and SK3 channels on PDGFR $\alpha^{+}$cells. ${ }^{30}$

\section{Vasoactive Intestinal Peptidergic Inhibitory Motor Innervation}

A third ultraslow non-nitrergic, non-purinergic neural pathway has been identified in the IAS. This pathway is present in the IAS of wildtype mice but absent from the VIP knockout mouse providing direct evidence for VIPergic NMT. ${ }^{122}$ In addition, non-nitrergic, non-purinergic inhibitory NMT is reduced by VIP antiserum and by VIP receptor antagonists in the rabbit and mouse IAS. ${ }^{119-122}$ Recently, an ultraslow non-nitrergic, non-purinergic neural pathway has also been identified in the monkey IAS that also appears to be due to VIP. ${ }^{30}$ Thus, inhibitory NMT in the monkey IAS consists of nitrergic and VIPergic NMT, whereas in the rectum it consists of nitrergic and purinergic NMT. It is possible that these regional differences reflect differences in the mechanism by which each pathway inhibits contraction. Whereas all three pathways generate IJPs that close voltage-gated $\mathrm{Ca}^{2+}$ channels, ie, electromechanical coupling, ${ }^{122,139}$ VIP and NO also decrease myofilament sensitization. ${ }^{61,145}$ Since myofilament sensitization is greater in the IAS than in non-sphincter muscles (eg, rectum), ${ }^{88,90}$ it is possible that nitrergic NMT in combination with VIPergic NMT is better suited to inhibiting contraction in the IAS whereas nitrergic in combination with purinergic NMT is better suited to the rectum where phasic contractions predominate.

\section{Summary}

The IAS exhibits a number of unique morphological and functional properties that are important for tone generation and the maintenance of high resting anal pressure. This review highlights four different mechanisms involved in tone generation. Each likely contributes in the IAS, with different emphasis occurring between species. Two mechanisms that give rise to tone through summation of phasic electrical events are presented. Thus, the conventional description of the IAS as a "purely tonic muscle" ${ }^{\text {"2 }}$ requires revision. Rather, the IAS is best represented as a phasically active muscle that generates tone. Electromechanical coupling mechanisms and $\mathrm{Ca}^{2+}$ sensitization may interact to generate tone and phasic contractions in the IAS (depicted in Fig. 7D). These interactions will be further modified by the actions of excitatory and inhibitory motor neurons. Advancing our knowledge of how IAS motility is controlled will 
require understanding the molecular basis for the mechanisms underlying tone generation as well as their modulation by nerves. This knowledge is critical for the development of effective treatment strategies for defecatory disorders.

Acknowledgements: The authors would like to express their appreciation to Drs Kenton M Sanders and Karen I Hannigan for their helpful insight and suggestions.

Financial support: This work was funded by NIDDK RO1 DK078736 to Kathleen D Keef and Caroline A Cobine.

\section{Conflicts of interest: None.}

Author contributions: Both Kathleen D Keef and Caroline A Cobine were involved in all aspects of this work including planning and conducting studies, collecting and interpreting data, and drafting this review.

\section{References}

1. Rao SS, Meduri K. What is necessary to diagnose constipation? Best Pract Res Clin Gastroenterol 2011;25:127-140.

2. Bharucha A. Anorectal disorders. In: Spiller R, Grundy D, eds. Pathophysiology of the enteric nervous system: a basis for understanding functional diseases. Oxford: Blackwell Publishing 2004:161-175.

3. Lestar B, Penninckx F, Kerremans R. The composition of anal basal pressure. An in vivo and in vitro study in man. Int $\mathrm{J}$ Colorectal Dis 1989;4:118-122.

4. Brading AF, Ramalingam T. Mechanisms controlling normal defecation and the potential effects of spinal cord injury. Prog Brain Res 2006;152:345-358.

5. Whitehead WE. Fecal incontinence: a neglected area of gastroenterology. Gastroenterology 2002;122:5.

6. Mundet L, Ribas Y, Arco S, Clavé P. Quality of life differences in female and male patients with fecal incontinence. J Neurogastroenterol Motil 2016;22:94-101.

7. Bharucha AE. Pelvic floor: anatomy and function. Neurogastroenterol Motil 2006;18:507-519.

8. Henning W, Deppen JG. Anal sphincterotomy, internal. StatPearls [Internet]. Treasure Island Florida: StatPearls Publishing LLC 2018.

9. Nelson RL, Manuel D, Gumienny C, et al. A systematic review and meta-analysis of the treatment of anal fissure. Tech Coloproctol 2017;21:605625.

10. Medhi B, Rao RS, Prakash A, Prakash O, Kaman L, Pandhi P. Recent advances in the pharmacotherapy of chronic anal fissure: an update. Asian J Surg 2008;31:154-163.

11. Mantoo S, Meurette G, Podevin J, Lehur PA. The magnetic anal sphincter: a new device in the management of severe fecal incontinence.
Expert Rev Med Devices 2012;9:483-490.

12. Wald A. Diagnosis and management of fecal incontinence. Curr Gastroenterol Rep 2018;20:9.

13. Trébol J, Carabias-Orgaz A, García-Arranz M, García-Olmo D. Stem cell therapy for faecal incontinence: current state and future perspectives. World J Stem Cells 2018;10:82-105.

14. Horiguchi K, Keef KD, Ward SM. Distribution of interstitial cells of Cajal in tunica muscularis of the canine rectoanal region. Am J Physiol Gastrointest Liver Physiol 2003;284:G756-G767.

15. Cobine CA, Hennig GW, Bayguinov YR, Hatton WJ, Ward SM, Keef $\mathrm{KD}$. Interstitial cells of Cajal in the cynomolgus monkey rectoanal region and their relationship to sympathetic and nitrergic nerves. Am J Physiol Gastrointest Liver Physiol 2010;298:G643-G656.

16. Hall KA, Ward SM, Cobine CA, Keef KD. Spatial organization and coordination of slow waves in the mouse anorectum. J Physiol 2014;592:3813-3829.

17. Rayment SJ, Eames T, Simpson JA, et al. Investigation of the distribution and function of alpha-adrenoceptors in the sheep isolated internal anal sphincter. Br J Pharmacol 2010;160:1727-1740.

18. Uz A, Elhan A, Ersoy M, Tekdemir I. Internal anal sphincter: an anatomic study. Clin Anat 2004;17:17-20.

19. Sanders KM, Kito Y, Hwang SJ, Ward SM. Regulation of gastrointestinal smooth muscle function by interstitial cells. Physiology (Bethesda) 2016;31:316-326.

20. Burns AJ, Lomax AE, Torihashi S, Sanders KM, Ward SM. Interstitial cells of Cajal mediate inhibitory neurotransmission in the stomach. Proc Natl Acad Sci USA 1996;93:12008-12013.

21. Ward SM, Sanders KM. Involvement of intramuscular interstitial cells of Cajal in neuroeffector transmission in the gastrointestinal tract. J Physiol 2006;576(Pt 3):675-682.

22. Ward SM, Beckett EA, Wang X, Baker F, Khoyi M, Sanders KM. Interstitial cells of Cajal mediate cholinergic neurotransmission from enteric motor neurons. J Neurosci 2000;20:1393-1403.

23. Cobine CA, Hennig GW, Kurahashi M, Sanders KM, Ward SM, Keef KD. Relationship between interstitial cells of Cajal, fibroblast-like cells and inhibitory motor nerves in the internal anal sphincter. Cell Tissue Res 2011;344:17-30.

24. Piotrowska AP, Solari V, Puri P. Distribution of interstitial cells of Cajal in the internal anal sphincter of patients with internal anal sphincter achalasia and hirschsprung disease. Arch Pathol Lab Med 2003;127:1192-1195.

25. Cobine CA, Foulkes HJL, Sanders KM, Baker SA, Keef KD. Visualization of pacemaker activity in intramuscular ICC in the Internal Anal Sphincter. In: Neurogastroenterol Motil. Hoboken, NJ USA: WileyBlackwell 2016;28:11-12.

26. Keef K, Ward S, Cobine C. Evidence supporting a pivotal role for intramuscular interstitial cells of Cajal in the generation of pacemaker activity, phasic contractions and tone in the internal anal sphincter. Transl Androl Urol 2016;5(suppl 2):S346.

27. Komuro T, Seki K, Horiguchi K. Ultrastructural characterization of the interstitial cells of Cajal. Arch Histol Cytol 1999;62:295-316.

28. Kurahashi M, Zheng H, Dwyer L, Ward SM, Koh SD, Sanders KM. A functional role for the 'fibroblast-like cells' in gastrointestinal smooth 
muscles. J Physiol 2011;589(Pt 3):697-710.

29. Sanders KM, Ward SM, Koh SD. Interstitial cells: regulators of smooth muscle function. Physiol Rev 2014;94:859-907.

30. Cobine CA, McKechnie M, Brookfield RJ, Hannigan KI, Keef KD. Comparison of inhibitory neuromuscular transmission in the cynomolgus monkey IAS and rectum: special emphasis on differences in purinergic transmission. J Physiol 2018;596:5319-5341.

31. Papasova M. Sphincteric function. In: Schultz SG, Wood JD, eds. Handbook of physiology: the gastrointestinal system. Washington DC: American Physiological Society 1989:987-1024.

32. Kubota M, Suita S, Szurszewski JH. Membrane properties and the neuro-effector transmission of smooth muscle cells in the canine internal anal sphincter. J Smooth Muscle Res 1998;34:173-184.

33. Mutafova-Yambolieva VN, O'Driscoll K, Farrelly A, Ward SM, Keef KD. Spatial localization and properties of pacemaker potentials in the canine rectoanal region. Am J Physiol Gastrointest Liver Physiol 2003;284:G748-G755.

34. Harvey N, McDonnell B, McKechnie M, Keef K. 475 Role of L-type calcium channels, membrane potential and nitric oxide in the control of myogenic activity in the primate internal anal sphincter. Gastroenterology 2008;134:A-63.

35. Duffy AM, Cobine CA, Keef KD. Changes in neuromuscular transmission in the $W / W^{v}$ mouse internal anal sphincter. Neurogastroenterol Motil 2012;24:e41-e55.

36. McDonnell B, Hamilton R, Fong M, Ward SM, Keef KD. Functional evidence for purinergic inhibitory neuromuscular transmission in the mouse internal anal sphincter. Am J Physiol Gastrointest Liver Physiol 2008;294:G1041-G1051.

37. Ward SM, Sanders KM. Upstroke component of electrical slow waves in canine colonic smooth muscle due to nifedipine-resistant calcium current. J Physiol 1992;455:321-337.

38. Kito Y, Mitsui R, Ward SM, Sanders KM. Characterization of slow waves generated by myenteric interstitial cells of Cajal of the rabbit small intestine. Am J Physiol Gastrointest Liver Physiol 2015;308:G378G388.

39. Kito Y, Ward SM, Sanders KM. Pacemaker potentials generated by interstitial cells of Cajal in the murine intestine. Am J Physiol Cell Physiol 2005;288:C710-C720.

40. Smith TK, Reed JB, Sanders KM. Interaction of two electrical pacemakers in muscularis of canine proximal colon. Am J Physiol 1987;252(3 Pt 1):C290-C299.

41. Rae MG, Fleming N, McGregor DB, Sanders KM, Keef KD. Control of motility patterns in the human colonic circular muscle layer by pacemaker activity. J Physiol 1998;510(Pt 1):309-320.

42. Rattan S. $\mathrm{Ca}^{2+} /$ calmodulin/MLCK pathway initiates, and RhoA/ROCK maintains, the internal anal sphincter smooth muscle tone. Am J Physiol Gastrointest Liver Physiol 2017;312:G63-G66.

43. Cook TA, Brading AF, Mortensen NJ. Effects of nifedipine on anorectal smooth muscle in vitro. Dis Colon Rectum 1999;42:782-787.

44. Cobine CA, Fong M, Hamilton R, Keef KD. Species dependent differences in the actions of sympathetic nerves and noradrenaline in the internal anal sphincter. Neurogastroenterol Motil 2007;19:937-945.
45. Opazo A, Lecea B, Gil V, Jiménez M, Clavé P, Gallego D. Specific and complementary roles for nitric oxide and ATP in the inhibitory motor pathways to rat internal anal sphincter. Neurogastroenterol Motil 2011;23:e11-e25.

46. Jonas-Obichere M, Scholefield JH, Acheson A, Mundey M, Tyler H, Wilson VG. Comparison of the effects of nitric oxide donors and calcium channel blockers on the intrinsic myogenic tone of sheep isolated internal anal sphincter. Br J Surg 2005;92:1263-1269.

47. Middleton SJ, Cuthbert AW, Shorthouse M, Hunter JO. Nitric oxide affects mammalian distal colonic smooth muscle by tonic neural inhibition. Br J Pharmacol 1993;108:974-979.

48. Mulé F, D'Angelo S, Amato A, Contino I, Serio R. Modulation by nitric oxide of spontaneous mechanical activity in rat proximal colon. J Auton Pharmacol 1999;19:1-6.

49. Fox-Threlkeld JE, Woskowska Z, Daniel EE. Sites of nitric oxide (NO) actions in control of circular muscle motility of the perfused isolated canine ileum. Can J Physiol Pharmacol 1997;75:1340-1349.

50. Yamato S, Spechler SJ, Goyal RK. Role of nitric oxide in esophageal peristalsis in the opossum. Gastroenterology 1992;103:197-204.

51. González AA, Farré R, Clavé P. Different responsiveness of excitatory and inhibitory enteric motor neurons in the human esophagus to electrical field stimulation and to nicotine. Am J Physiol Gastrointest Liver Physiol 2004;287:G299-G306.

52. Imaizumi Y, Muraki K, Takeda M, Watanabe M. Measurement and simulation of noninactivating Ca current in smooth muscle cells. Am J Physiol 1989;256(4 Pt 1):C880-C885.

53. Langton PD, Standen NB. Calcium currents elicited by voltage steps and steady voltages in myocytes isolated from the rat basilar artery. J Physiol 1993;469:535-548.

54. Fleischmann BK, Murray RK, Kotlikoff MI. Voltage window for sustained elevation of cytosolic calcium in smooth muscle cells. Proc Natl Acad Sci USA 19946;91:11914-11918.

55. Zhu HL, Hirst GD, Ito Y, Teramoto N. Modulation of voltage-dependent $\mathrm{Ba}^{2+}$ currents in the guinea-pig gastric antrum by cyclic nucleotidedependent pathways. Br J Pharmacol 2005;146:129-138.

56. Keef KD, Hume JR, Zhong J. Regulation of cardiac and smooth muscle $\mathrm{Ca}^{2+}$ channels (CaV1.2a,b) by protein kinases. Am J Physiol Cell Physiol 2001;281:C1743-C1756.

57. Berridge MJ. Smooth muscle cell calcium activation mechanisms. J Physiol 20081;586:5047-5061.

58. Desch M, Sigl K, Hieke B, et al. IRAG determines nitric oxide- and atrial natriuretic peptide-mediated smooth muscle relaxation. Cardiovasc Res 2010;86:496-505.

59. Himpens B, Matthijs G, Somlyo AP. Desensitization to cytoplasmic $\mathrm{Ca}^{2+}$ and $\mathrm{Ca}^{2+}$ sensitivities of guinea-pig ileum and rabbit pulmonary artery smooth muscle. J Physiol 1989;413:489-503.

60. Etter EF, Eto M, Wardle RL, Brautigan DL, Murphy RA. Activation of myosin light chain phosphatase in intact arterial smooth muscle during nitric oxide-induced relaxation. J Biol Chem 2001;276:34681-34685.

61. Nakamura K, Koga Y, Sakai H, Homma K, Ikebe M. cGMP-dependent relaxation of smooth muscle is coupled with the change in the phosphorylation of myosin phosphatase. Circ Res 2007;101:712-722. 
62. Chipperfield AR, Harper AA. Chloride in smooth muscle. Prog Biophys Mol Biol 2000;74:175-221.

63. Gomez-Pinilla PJ, Gibbons SJ, Bardsley MR, et al. Ano1 is a selective marker of interstitial cells of Cajal in the human and mouse gastrointestinal tract. Am J Physiol Gastrointest Liver Physiol 2009;296:G1370G1381.

64. Hwang SJ, Blair PJ, Britton FC, et al. Expression of anoctamin 1/ TMEM16A by interstitial cells of Cajal is fundamental for slow wave activity in gastrointestinal muscles. J Physiol 200915;587(Pt 20):48874904.

65. Lee MY, Ha SE, Park C, et al. Transcriptome of interstitial cells of Cajal reveals unique and selective gene signatures. PLoS One 2017;12:e0176031.

66. Lee MY, Park C, Berent RM, et al. Smooth muscle cell genome browser: enabling the identification of novel serum response factor target genes. PLoS One 2015;10:e0133751.

67. Zhu MH, Kim TW, Ro S, et al. A Ca ${ }^{2+}$-activated $\mathrm{Cl}^{-}$conductance in interstitial cells of Cajal linked to slow wave currents and pacemaker activity. J Physiol 2009;587(Pt 20):4905-4918.

68. Malysz J, Gibbons SJ, Saravanaperumal SA, et al. Conditional genetic deletion of Ano1 in interstitial cells of Cajal impairs $\mathrm{Ca}^{2+}$ transients and slow waves in adult mouse small intestine. Am J Physiol Gastrointest Liver Physiol 2017;312:G228-G245.

69. Sanders KM, Zhu MH, Britton F, Koh SD, Ward SM. Anoctamins and gastrointestinal smooth muscle excitability. Exp Physiol 2012;97:200206.

70. Cobine CA, Hannah EE, Zhu MH, et al. ANO1 in intramuscular interstitial cells of Cajal plays a key role in the generation of slow waves and tone in the internal anal sphincter. J Physiol 2017;595:2021-2041.

71. Martini FH, Nath JL, Batholomew EF. Anatomy and physiology. New York:Prentice Hall 2005:209-240.

72. Caputo C, Edman KA, Lou F, Sun YB. Variation in myoplasmic $\mathrm{Ca}^{2+}$ concentration during contraction and relaxation studied by the indicator fluo-3 in frog muscle fibres. J Physiol 1994;478(Pt 1):137-148.

73. Cobine C, Hannigan K, McMahon M, Bhraonain EN, Keef K. Phasic activity and tone in the internal anal sphincter: role of calcium entry and stretch. Neurogastroenterol Motil 2018;30(suppl 1):e13423.

74. Lang RJ. The whole-cell $\mathrm{Ca}^{2+}$ channel current in single smooth muscle cells of the guinea-pig ureter. J Physiol 1990;423:453-473.

75. Vogalis F, Publicover NG, Hume JR, Sanders KM. Relationship between calcium current and cytosolic calcium in canine gastric smooth muscle cells. Am J Physiol 1991;260(5 Pt 1):C1012-C1018.

76. Sims SM. Calcium and potassium currents in canine gastric smooth muscle cells. Am J Physiol 1992;262(5 Pt 1):G859-G867.

77. Fransen P, Van Hove CE, van Langen J, et al. Contribution of transient and sustained calcium influx, and sensitization to depolarization-induced contractions of the intact mouse aorta. BMC Physiol 2012;12:9.

78. Bauer AJ, Sanders KM. Gradient in excitation-contraction coupling in canine gastric antral circular muscle. J Physiol 1985;369:283-294.

79. Somlyo AP, Somlyo AV. Signal transduction by g-proteins, rho-kinase and protein phosphatase to smooth muscle and non-muscle myosin II. J Physiol 2000;522 Pt 2:177-185.
80. Somlyo AP, Somlyo AV. Signal transduction through the rhoA/rho-kinase pathway in smooth muscle. J Muscle Res Cell Motil 2004;25:613-615.

81. Matsumura F, Hartshorne DJ. Myosin phosphatase target subunit: many roles in cell function. Biochem Biophys Res Commun 2008;369:149-156.

82. Hartshorne DJ, Ito M, Erdödi F. Role of protein phosphatase type 1 in contractile functions: myosin phosphatase. J Biol Chem 2004;279:3721137214.

83. Grassie ME, Moffat LD, Walsh MP, MacDonald JA. The myosin phosphatase targeting protein (MYPT) family: a regulated mechanism for achieving substrate specificity of the catalytic subunit of protein phosphatase type 1delta. Arch Biochem Biophys 2011;510:147-159.

84. Velasco G, Armstrong C, Morrice N, Frame S, Cohen P. Phosphorylation of the regulatory subunit of smooth muscle protein phosphatase $1 \mathrm{M}$ at Thr850 induces its dissociation from myosin. FEBS Lett 2002;527:101-104.

85. Gao N, Chang AN, He W, et al. Physiological signalling to myosin phosphatase targeting subunit-1 phosphorylation in ileal smooth muscle. J Physiol 2016;594:3209-3225.

86. Perrino BA. Calcium sensitization mechanisms in gastrointestinal smooth muscles. J Neurogastroenterol Motil 2016;22:213-225.

87. Patel CA, Rattan S. Cellular regulation of basal tone in internal anal sphincter smooth muscle by RhoA/ROCK. Am J Physiol Gastrointest Liver Physiol 2007;292:G1747-G1756.

88. Patel CA, Rattan S. Spontaneously tonic smooth muscle has characteristically higher levels of RhoA/ROK compared with the phasic smooth muscle. Am J Physiol Gastrointest Liver Physiol 2006;291:G830-G837.

89. Rattan S, Patel CA. Selectivity of ROCK inhibitors in the spontaneously tonic smooth muscle. Am J Physiol Gastrointest Liver Physiol 2008;294:G687-G693.

90. Rattan S, Singh J. RhoA/ROCK pathway is the major molecular determinant of basal tone in intact human internal anal sphincter. Am J Physiol Gastrointest Liver Physiol 2012;302:G664-G675.

91. Cobine CA, Bhetwal BP, Stever JR, Keef KD, Perrino BA. Comparison of proteins involved in the regulation of myosin light chain $[\mathrm{mlc}(20)]$ phosphorylation in the monkey ias and rectum. Neurogastroenterol Motil 2013;25:43.

92. Tichenor SD, Buxton IL, Johnson P, O'Driscoll K, Keef KD. Excitatory motor innervation in the canine rectoanal region: role of changing receptor populations. Br J Pharmacol 2002;137:1321-1329.

93. Acheson A, Rayment S, Eames T, et al. Investigation of the role of adrenergic and non-nitrergic, non-adrenergic neurotransmission in the sheep isolated internal anal sphincter. Neurogastroenterol Motil 2009;21:335345 .

94. Glavind EB, Forman A, Madsen G, Tøttrup A. Effects of transmural field stimulation in isolated smooth muscle of human rectum and internal anal sphincter. Am J Physiol 1997;272(5 Pt 1):G1075-G1082.

95. Krier J. Motor function of anorectum and pelvic floor musculature. Handbook of Physiology. The Gastrointestinal System. Motility and Circulation 1989:1025-1053.

96. Spencer N, McCarron SL, Smith TK. Sympathetic inhibition of ascending and descending interneurones during the peristaltic reflex in the iso- 
lated guinea-pig distal colon. J Physiol 1999;519(Pt 2):539-50.

97. Kinugasa Y, Arakawa T, Murakami G, Fujimiya M, Sugihara K. Nerve supply to the internal anal sphincter differs from that to the distal rectum: an immunohistochemical study of cadavers. Int J Colorectal Dis 2014;29:429-436.

98. Bharucha AE, Brookes SJ. Neurophysiologic mechanisms of human large intestinal motility. In: Said HM, ed. Physiology of the Gastrointestinal Tract. 6 ed. Elsevier. 2018:517-564.

99. Carlstedt A, Fasth S, Hultén L, Nordgren S. The sympathetic innervation of the internal anal sphincter and rectum in the cat. Acta Physiol Scand 1988;133:423-431.

100. Carlstedt A, Nordgren S, Fasth S, Appelgren L, Hultén L. Sympathetic nervous influence on the internal anal sphincter and rectum in man. Int J Colorectal Dis 1988;3:90-95.

101. Bouvier M, Gonella J. Nervous control of the internal anal sphincter of the cat. J Physiol 1981;310:457-469.

102. Garrett JR, Howard ER, Jones W. The internal anal sphincter in the cat: a study of nervous mechanisms affecting tone and reflex activity. J Physiol 1974;243:153-166.

103. Rayner V. Characteristics of the internal anal sphincter and the rectum of the vervet monkey. J Physiol 1979;286:383-399.

104. Hedlund H, Fasth S, Hultén L. Efferent sympathetic nervous control of rectal motility in the cat. Acta Physiol Scand 1984;121:317-324.

105. Frenckner B, Ihre T. Influence of autonomic nerves on the internal and sphincter in man. Gut 1976;17:306-312.

106. Mizutani M, Neya T, Ono K, Yamasato T, Tokunaga A. Histochemical study of the lumbar colonic nerve supply to the internal anal sphincter and its physiological role in dogs. Brain Res 1992;598:45-50.

107. Furness JB, Costa $M$. The ramifications of adrenergic nerve terminals in the rectum, anal sphincter and anal accessory muscles of the guinea-pig. Z Anat Entwicklungsgesch 1973;140:109-28.

108. Owaki H, Sadahiro S, Takaki M. Characterizations of the alpha1adrenoceptor subtypes mediating contractions of the human internal anal sphincter. J Pharmacol Sci 2015;127:424-429.

109. Mills K, Hausman N, Chess-Williams R. Characterization of the alpha1adrenoceptor subtype mediating contractions of the pig internal anal sphincter. Br J Pharmacol 2008;155:110-117.

110. O'Kelly TJ. Nerves that say NO: a new perspective on the human rectoanal inhibitory reflex. Ann R Coll Surg Engl 1996;78:31-38.

111.Stebbing JF, Brading AF, Mortensen NJ. Nitric oxide and the rectoanal inhibitory reflex: retrograde neuronal tracing reveals a descending nitrergic rectoanal pathway in a guinea-pig model. Br J Surg 1996;83:493-498.

112. Stebbing JF. Nitric oxide synthase neurones and neuromuscular behaviour of the anorectum. Ann R Coll Surg Engl 1998;80:137-145.

113. Broens PM, Penninckx FM, Ochoa JB. Fecal continence revisited: the anal external sphincter continence reflex. Dis Colon Rectum 2013;56:1273-1281.

114. Cheeney G, Nguyen M, Valestin J, Rao SS. Topographic and manometric characterization of the recto-anal inhibitory reflex. Neurogastroenterol Motil 2012;24:e147-e154.

115.De Ocampo S, Remes-Troche JM, Miller MJ, Rao SS. Rectoanal sensorimotor response in humans during rectal distension. Dis Colon Rectum
2007;50:1639-1646

116. Bajwa A, Emmanuel A. The physiology of continence and evacuation. Best Pract Res Clin Gastroenterol 2009;23:477-485.

117. Terauchi A, Kobayashi D, Mashimo H. Distinct roles of nitric oxide synthases and interstitial cells of Cajal in rectoanal relaxation. Am J Physiol Gastrointest Liver Physiol 2005;289:G291-G299.

118. de Lorijn F, de Jonge WJ, Wedel T, Vanderwinden JM, Benninga MA, Boeckxstaens GE. Interstitial cells of Cajal are involved in the afferent limb of the rectoanal inhibitory reflex. Gut 2005;54:1107-1113.

119. Knudsen MA, Glavind EB, Tøttrup A. Transmitter interactions in rabbit internal anal sphincter. Am J Physiol 1995;269(2 Pt 1):G232-G239.

120. Biancani P, Walsh J, Behar J. Vasoactive intestinal peptide: a neurotransmitter for relaxation of the rabbit internal anal sphincter. Gastroenterology 1985;89:867-874.

121. Rattan S, Regan RF, Patel CA, De Godoy MA. Nitric oxide not carbon monoxide mediates nonadrenergic noncholinergic relaxation in the murine internal anal sphincter. Gastroenterology 2005;129:1954-1966.

122. Keef KD, Saxton SN, McDowall RA, Kaminski RE, Duffy AM, Cobine CA. Functional role of vasoactive intestinal polypeptide in inhibitory motor innervation in the mouse internal anal sphincter. J Physiol 2013;591:1489-1506.

123. Folasire O, Mills KA, Sellers DJ, Chess-Williams R. Three gaseous neurotransmitters, nitric oxide, carbon monoxide, and hydrogen sulfide, are involved in the neurogenic relaxation responses of the porcine internal anal sphincter. J Neurogastroenterol Motil 2016;22:141-148.

124. O'Kelly T, Brading A, Mortensen N. Nerve mediated relaxation of the human internal anal sphincter: the role of nitric oxide. Gut 1993;34:689693.

125. Cobine CA, Sotherton AG, Peri LE, Sanders KM, Ward SM, Keef KD. Nitrergic neuromuscular transmission in the mouse internal anal sphincter is accomplished by multiple pathways and post-junctional effector cells. Am J Physiol Gastrointest Liver Physiol 2014;307:G1057G1072.

126. Blair PJ, Rhee PL, Sanders KM, Ward SM. The significance of interstitial cells in neurogastroenterology. J Neurogastroenterol Motil 2014;20:294-317.

127. Iino S, Horiguchi S, Horiguchi K, Nojyo Y. Interstitial cells of Cajal in the gastrointestinal musculature of $\mathrm{W}$ mutant mice. Arch Histol Cytol 2007;70:163-173.

128. De Man JG, De Winter BY, Herman AG, Pelckmans PA. Study on the cyclic GMP-dependency of relaxations to endogenous and exogenous nitric oxide in the mouse gastrointestinal tract. Br J Pharmacol 2007;150:88-96.

129. Franck H, Sweeney KM, Sanders KM, Shuttleworth CW. Effects of a novel guanylate cyclase inhibitor on nitric oxide- dependent inhibitory neurotransmission in canine proximal colon. Br J Pharmacol 1997;122:1223-1229.

130.Lincoln TM, Komalavilas P, Boerth NJ, MacMillan-Crow LA, Cornwell TL. cGMP signaling through cAMP- and cGMP-dependent protein kinases. Adv Pharmacol 1995;34:305-22:305-322.

131. Francis SH, Busch JL, Corbin JD, Sibley D. cGMP-dependent protein kinases and cGMP phosphodiesterases in nitric oxide and cGMP action. 
Pharmacol Rev 2010;62:525-563.

132. Bender AT, Beavo JA. Cyclic nucleotide phosphodiesterases: molecular regulation to clinical use. Pharmacol Rev 2006;58:488-520.

133. Kitazawa T, Somlyo AP. Desensitization and muscarinic re-sensitization of force and myosin light chain phosphorylation to cytoplasmic $\mathrm{Ca}^{2+}$ in smooth muscle. Biochem Biophys Res Commun 1990;172:1291-1297.

134.Lee MR, Li L, Kitazawa T. Cyclic GMP causes $\mathrm{Ca}^{2+}$ desensitization in vascular smooth muscle by activating the myosin light chain phosphatase. J Biol Chem 1997;272:5063-5068.

135. Sausbier M, Schubert R, Voigt V, et al. Mechanisms of NO/cGMPdependent vasorelaxation. Circ Res 2000;87:825-830.

136. Bonnevier J, Arner A. Actions downstream of cyclic GMP/protein kinase $\mathrm{G}$ can reverse protein kinase $\mathrm{C}$-mediated phosphorylation of CPI-17 and $\mathrm{Ca}^{2+}$ sensitization in smooth muscle. J Biol Chem 2004;279:2899829003.

137. Burnstock G, Campbell G, Satchell D, Smythe A. Evidence that adenosine triphosphate or a related nucleotide is the transmitter substance released by non-adrenergic inhibitory nerves in the gut. $\mathrm{Br} \mathrm{J}$ Pharmacol 1970;40:668-688.

138. Gallego D, Hernández P, Clavé P, Jiménez M. P2Y1 receptors mediate inhibitory purinergic neuromuscular transmission in the human colon. Am J Physiol Gastrointest Liver Physiol 2006;291:G584-G594.

139. Gallego D, Mañé N, Gil V, Martinez-Cutillas M, Jiménez M. Mecha- nisms responsible for neuromuscular relaxation in the gastrointestinal tract. Rev Esp Enferm Dig 2016;108:721-731.

140. Horiguchi K, Komuro T. Ultrastructural observations of fibroblast-like cells forming gap junctions in the $W / W^{V}$ mouse small intestine. J Auton Nerv Syst 2000;80:142-147.

141. Kurahashi M, Nakano Y, Hennig GW, Ward SM, Sanders KM. Platelet-derived growth factor receptor alpha-positive cells in the tunica muscularis of human colon. J Cell Mol Med 2012;16:1397-1404.

142.Baker SA, Hennig GW, Salter AK, Kurahashi M, Ward SM, Sanders KM. Distribution and $\mathrm{Ca}^{2+}$ signalling of fibroblast-like $\left(\mathrm{PDGFR}^{+}\right)$ cells in the murine gastric fundus. J Physiol 2013;591:6193-6208.

143. Kurahashi M, Mutafova-Yambolieva V, Koh SD, Sanders KM. Plateletderived growth factor receptor alpha-positive cells and not smooth muscle cells mediate purinergic hyperpolarization in murine colonic muscles. Am J Physiol Cell Physiol 2014;307:C561-C570.

144. Rae MG, Muir TC. Neuronal mediators of inhibitory junction potentials and relaxation in the guinea-pig internal anal sphincter. J Physiol 1996;493(Pt 2):517-527.

145. Khromov AS, Momotani K, Jin L, Artamonov MV, Shannon J, Eto M, Somlyo AV. Molecular mechanism of telokin-mediated disinhibition of myosin light chain phosphatase and cAMP/cGMP-induced relaxation of gastrointestinal smooth muscle. J Biol Chem 2012;287:20975-20985. 